\title{
Development of a hot water disinfestation treatment for taro exported from the Pacific Islands
}

\author{
L.E. Jamieson ${ }^{1}$, A. Chhagan ${ }^{1}$, S.P. Redpath ${ }^{1}$, M.J. Griffin ${ }^{1}$, C. Rohan ${ }^{2}$, F. Tunupopo ${ }^{3}$, \\ A. Tugaga ${ }^{3}$, P.G. Connolly ${ }^{1}$ and A.B. Woolf ${ }^{1}$ \\ ${ }^{1}$ The New Zealand Institute for Plant \& Food Research Limited, PO Box 92169 Mt Albert, \\ Auckland \\ ${ }^{2}$ AgResearch Ltd, Ruakura Research Centre, Private Bag 3123, Hamilton \\ ${ }^{3} \mathrm{Nu}$ 'u Research Station, Apia, Samoa \\ Corresponding author: Simon.redpath@plantandfood.co.nz
}

\begin{abstract}
Taro imported to New Zealand from the Pacific Islands are currently fumigated with methyl bromide (MB) for control of mites, nematodes and other quarantine pests. There are growing restrictions on the use of $\mathrm{MB}$, and alternatives to this fumigant are being sought, such as hot water treatments. Mites (Rhizoglyphus minutus) and nematodes (Meloidogyne sp. or Helicotylenchus sp.) were exposed to hot water both 'on' and 'off' taro. Hot water exposures ranged from $47.5^{\circ} \mathrm{C}$ to $52.5^{\circ} \mathrm{C}$ for $15 \mathrm{~s}$ to $5 \mathrm{~min}$, the duration depending on the temperature. Preliminary 'off taro' experiments indicated that $100 \%$ mortality of $R$. minutus mite adults was achieved in $3-4 \mathrm{~min}$ at $47.5^{\circ} \mathrm{C}$, and between $30 \mathrm{~s}$ and $1 \mathrm{~min}$ at $50^{\circ} \mathrm{C}$. All adult mites were dead at the shortest treatment duration $(15 \mathrm{~s})$ at $52.5^{\circ} \mathrm{C}$. The results indicated that $100 \%$ mortality of juvenile Meloidogyne sp. was achieved in $1-2 \mathrm{~min}$ at $47.5^{\circ} \mathrm{C}$, and between $30 \mathrm{~s}$ and $1 \mathrm{~min}$ at $50^{\circ} \mathrm{C}$. All juvenile nematodes were dead at $45 \mathrm{~s}$ at $52.5^{\circ} \mathrm{C}$. Preliminary 'on taro' experiments at $52.5^{\circ} \mathrm{C}$ for durations of $3.5 \mathrm{~min}$ and $5 \mathrm{~min}$ indicated that a longer duration would be required to achieve $100 \%$ mortality of Rhizoglyphus mites. No live Meloidogyne or Helicotylenchus nematodes were present in either the untreated or hot water-treated taro.
\end{abstract}

Keywords biosecurity, disinfestation, taro, quarantine treatment, risk mitigation, taro mite, root knot nematode, hot water, heat treatment.

\section{INTRODUCTION}

The New Zealand Ministry for Primary Industries requires that the fresh corms of imported root crops, such as taro and yam from the Pacific Islands, are free of quarantine pests (MPI 2012). Organisms that are frequently carried on corms include mites, nematodes, ants, snails and larvae of soil-dwelling beetles (Page-Weir et al. 2013). Existing border treatment protocols for root crops require fumigation with methyl bromide (MB) on arrival when pests are detected (MPI 2012). Although not all pests found on the products are 'unwanted organisms', importers often choose to have their consignment fumigated and released immediately, rather than wait for the organisms in question to 
be identified by MPI. This results in fumigation of most consignments, many possibly unnecessarily.

Although MB fumigation can ensure freedom from live pests, many fresh products, including root crops, exhibit post-fumigation physiological damage that significantly reduces storage quality (Anon 2016; De Lima 2009). MB is an ozone-depleting substance and is being phased out. However, its uses for quarantine and pre-shipment purposes are currently exempt (UNEP 2012). The reduction in $\mathrm{MB}$ consumption for most of its uses has decreased production and increased the cost of the product. In the future, MB may become both difficult to obtain and more costly to use as a fumigant. Like many other countries, New Zealand is seeking alternative treatments to $\mathrm{MB}$ that will eliminate or reduce the potential for unwanted organisms to be found on arrival on imported produce, while maintaining the quality of the produce in the market.

Previous research indicated that taro corms tolerated hot water treatment (HWT) up to $60 \mathrm{~min}$ at $45-50^{\circ} \mathrm{C}$ or up to $30 \mathrm{~min}$ at $55^{\circ} \mathrm{C}$ (Brash \& van Epenhuijsen 2006). The effects of these treatments on subsequent storage quality, especially on the development of rots, could not be assessed because the corms were purchased in New Zealand and their handling and storage conditions during transit were unknown. It was also unknown if the corms had been fumigated on arrival. Subsequent trials indicated that a heat treatment of 10-14 min at $50-51{ }^{\circ} \mathrm{C}$ was found to control pests and that maintain good corm quality (Buli et al. 2015). However, the number of mites and nematodes in the naturally infested taro corms used in the trial were insufficient to assess treatment efficacy.

The previous research (Brash \& van Epenhuijsen 2006, Buli et al. 2015) indicated that hot water immersion has the potential to disinfest taro corms in the country of origin. It reduces or eliminates live mites, nematodes or other unwanted organisms being detected on arrival in New Zealand, while maintaining acceptable taro corm quality and marketability. A study conducted by Page-Weir et al. (2013) in New Zealand showed that a 3-6 min HWT at $48-49^{\circ} \mathrm{C}$ killed $99 \%$ of adult mould mite, Tyrophagus putrescentiae and juvenile root knot nematode Meliodogyne nr incognita.

The objective of this research was to assess the potential for HWT to control mite and nematode species on taro imported into New Zealand, while maintaining the marketability of the product.

\section{MATERIALS AND METHODS Collection and identification of mites and nematodes}

Taro corms were collected from the Nu'u Research Station and a neighbouring property, on Upolu Island, Samoa. The taro were new varieties, 'Samoa 1 ' and 'Samoa 2', which are tolerant to taro leaf blight (Phytophthora colocasiae). Taro corms were brought back to the laboratory and inspected for live mites using a hand lens. Soil from the taro corms was also inspected for mites using a microscope. Mites were removed from the taro and associated soil for use in subsequent experiments using a fine hair paintbrush. These mites were officially identified as the taro mite, Rhizoglyphus minutus.

Root knot nematode cultures on taro and tomato were established in a nematode-free growth medium and maintained in a shade house at Nu'u Research Station in July 2014. In November 2014, heavily galled roots from tomato plants and deformed roots from taro plants were carefully removed. They were washed separately with tap water in a laboratory to extract any nematodes. Pieces of heavily galled tomato and taro roots were placed in separate plastic trays and covered with $100 \mathrm{ml}$ of distilled water. The roots were crushed with a small roller. The crushed suspension was sieved through nested 500 and $20 \mu \mathrm{m}$ sieves, the first to remove the debris and the second to collect the nematode second stage juveniles (J2) and eggs. The juveniles and eggs trapped in the 20 $\mu \mathrm{m}$ sieve were thoroughly washed with distilled water and $1 \mathrm{ml}$ of suspension was placed into a Doncaster dish and observed using a low-powered stereoscopic dissecting microscope. A large number of embryonated eggs were observed.

The collected suspension was poured over two layers of kimwipes ${ }^{\mathrm{Tw}}$ tissues standing on a 1 $\mathrm{mm}$ wire mesh in a glass Petri dish. Sufficient 
water was added to the Petri dish to cover the tissues in the dishes. These were kept overnight to separate juveniles, which moved through the tissue paper, while eggs and root debris trapped on the tissues. Juveniles were collected in a small beaker with distilled water which served as a stock solution. Approximately $10 \mathrm{ml}$ of stock solution was transferred into a Doncaster counting dish for counting and standardising the nematode suspension. A sample of nematode specimens was inspected under a compound microscope and identified as Meloidogyne sp.

\section{Hot water trials of mites and nematodes 'off taro'}

A series of trials were conducted in Samoa to determine the time/temperature mortality responses 'off taro' of $R$. minutus mites and Meloidogyne sp. nematodes to hot water. Adult $R$. minutus mites were removed from infested, field-collected taro corms and placed in glass tubes (74 mm length x $24 \mathrm{~mm}$ diameter) fitted with fine mesh gauze (200 squares per inch, $0.085 \mathrm{~mm}$ aperture). Each vial also contained a very small piece of decomposing taro. Prior to fitting each lid, Parafilm ${ }^{\circledR}$ was wrapped around the thread to ensure a tight-fitting seal. Each vial represented one replicate, with three vials being treated per temperature/time combination. Each vial contained ca 50 adult mites. The vials were held overnight before treatment on a tray lined with moistened paper towels and covered with a plastic bag to retain humidity.

Groups of 20 active Meloidogyne sp. nematode juveniles were placed into $4 \mathrm{ml}$ glass vials with a pipette (Brand GMBH \& Co micro-classic pulled pipette), using a microscope at 20-40 times magnification. The vial was subsequently filled with $2 \mathrm{ml}$ of distilled water. Vials with nematodes were labelled and kept in a refrigerator at about $4^{\circ} \mathrm{C}$ overnight before treatment.

Treatments were conducted in custom-built, stainless steel water baths. A water bath heater (Grant instruments, Cambridge, UK) was used to heat the water. Temperature probes were placed in the middle and at the edge of each bath. In the 'off taro' trials, a temperature probe was also placed in an empty vial within each bath. All treatment vials containing mites or nematodes were submerged using a metal grid. Untreated air control vials remained at ambient temperature $\left(\mathrm{ca} 22^{\circ} \mathrm{C}\right.$ ) during the treatment. Water control vials were immersed in water at ca $22^{\circ} \mathrm{C}$. Hot water treatment temperatures and durations are shown in Table 1.

After the treatment, the mite and nematode vials were placed in a cooling bath (water at ambient temperature $\left(\mathrm{ca} 25^{\circ} \mathrm{C}\right)$ for approximately $10 \mathrm{~s}$. After draining the water, the vials were placed on towels and left to dry for approximately $1 \mathrm{~h}$. The mites were stored for $24 \mathrm{~h}$ at ambient temperature $\left(\mathrm{ca} 22^{\circ} \mathrm{C}\right)$ (covered with a plastic bag to maintain high humidity) before their viability was assessed. The nematodes were stored for 24 $\mathrm{h}$ at $4^{\circ} \mathrm{C}$ before their viability was assessed. Mite viability was assessed using a stereo-microscope at 40x magnification. The mites were classified as live when they moved after being gently prodded, or dead if there was no movement. Treated nematodes within the suspension were transferred to the centre of a Doncaster counting dish for the viability assessment. Nematode viability was assessed under a transmitted light stereo-microscope at 20-40 times magnification. Nematodes were classified as live if they were active, dead if their body was straight and moribund if the body was still and

Table 1 Temperatures and durations used in the mite and nematode hot water treatments 'off taro'.

\begin{tabular}{lccccc}
\hline Treatment & Duration 1 & Duration 2 & Duration 3 & Duration 4 & Duration 5 \\
\hline Air control & & & & & $5 \mathrm{~min}$ \\
Water control & $60 \mathrm{~s}$ & $90 \mathrm{~s}$ & $3 \mathrm{~min}$ & $4 \mathrm{~min}$ & $5 \mathrm{~min}$ \\
$47.5^{\circ} \mathrm{C}$ & $60 \mathrm{~s}$ & $2 \mathrm{~min}$ & $3 \mathrm{~min}$ & $4 \mathrm{~min}$ & $5 \mathrm{~min}$ \\
$50.0^{\circ} \mathrm{C}$ & $30 \mathrm{~s}$ & $60 \mathrm{~s}$ & $90 \mathrm{~s}$ & $2 \mathrm{~min}$ & $3 \mathrm{~min}$ \\
$52.5^{\circ} \mathrm{C}$ & $15 \mathrm{~s}$ & $30 \mathrm{~s}$ & $45 \mathrm{~s}$ & $60 \mathrm{~s}$ & $90 \mathrm{~s}$ \\
\hline
\end{tabular}


curved and there was no movement. As moribund nematodes have a moderate to low risk of reinvading roots, they were subsequently classified as dead.

\section{Hot water treatment of mites and nematodes 'on taro'}

Trials were conducted with mites and nematodes 'on taro' to estimate how much longer immersion times would need to be to achieve high mortality when mites and nematodes were in situ in protected parts of the taro corm. $R$. minutus mites were removed from infested field-collected taro corms and brushed onto clean taro corms ('Samoa 2'). The corns were cleaned by removing the roots and dead leaves, cutting off the long leaf bases and hand-washing them. In addition, at least three deformed taro corms were included in each treatment so that corms naturally infested with nematodes could be treated. The taro corms were then placed into buckets lined with moistened paper towels and covered with a plastic cover to allow the mites to settle onto the taro corms overnight. The plastic cover may have helped to retain a high humidity in each bucket. The next day, the taro corms were inspected for mites using a hand lens. Mite-infested taro were randomly assigned to hot water treatments.

Infested taro were treated in large fibreglass tubs (filled to a volume of 95 litres) with Grant temperature controller units $\left( \pm 0.1^{\circ} \mathrm{C}, 1.4 \mathrm{~kW}\right.$ heater; model GRAVF, UK) attached, and with the stirrer blade removed. Uniform water distribution, and thus temperature within the baths, was achieved by re-circulating water with a pump (model UPS 20-60B 150; Grundfos pumps, Denmark) past the heater, through perforated PVC tubing (22-mm ID) arranged in a grid pattern located in the base of the baths. Additional heating at the time of corm immersion was provided using manually-operated Eutron (Auckland, New Zealand) water heaters $(2.3 \mathrm{~kW})$. The temperature was measured at the "return" position in the bath. Preliminary experiments were carried out that determined 30-45 s was required for additional heat to obtain the target temperature before the corms were immersed. Additional heating during treatment was sometimes required, particularly at higher temperatures. This system resulted in water temperatures varying by no more than $\pm 0.2^{\circ} \mathrm{C}$ in space and time.

A total of seven mite-infested taro (including three galled taro) were used per treatment and ten mite-infested taro (including three galled taro) were used for the air control. Taro were placed into a plastic-coated wire mesh basket with another basket on top to keep the taro submerged. Taro were treated for either 3.5 or 5 min at either ambient (ca $22^{\circ} \mathrm{C}$ ) or $52.5^{\circ} \mathrm{C}$.

Following HWT, the corms were cooled by hydrocooling for ca $3 \mathrm{~min}$ in buckets of tap-water at ca $25^{\circ} \mathrm{C}$. The corms were then laid out in the evaluation room at an ambient temperature ca $20-35^{\circ} \mathrm{C}$. Taro were inspected $24 \mathrm{~h}$ after treatment using a hand lens and a microscope. The number of live and dead mites and nematodes were recorded, as described in the 'off taro' trials.

\section{Statistical analysis}

To assess the mortality response (shown in Figures 1 and 2), non-parametric LOESS fits (Cleveland et al. 1992) were calculated and plotted on an angular transformed scale (e.g. transform percentage $\mathrm{p}$ by $\arcsin [\operatorname{sqrt}(\mathrm{p} / 100)]$ ) in $\mathrm{R}$ (R Core Team 2015). For each temperature, smoothed lines were drawn through the percentage mortality points after exposure to HWT, at each treatment time. The error bars in Figures 1 and 2 represent approximately uniform variability over the entire mortality range on the arcsine scale.

\section{RESULTS \\ 'Off taro' mite and nematode mortality responses}

One hundred percent mortality of $R$. minutus mites was achieved in $3-4 \mathrm{~min}$ at $47.5^{\circ} \mathrm{C}$, and between $30 \mathrm{~s}$ and $1 \mathrm{~min}$ at $50^{\circ} \mathrm{C}$ (Figure 1). All mites were dead at the shortest treatment 


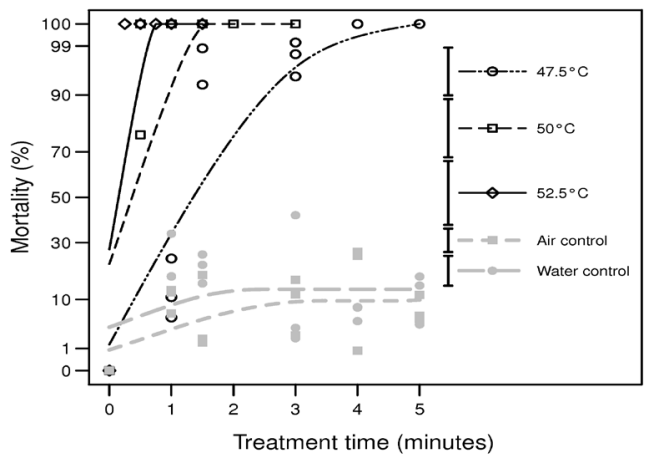

Figure 1 Percentage mortality of Rhizoglyphus minutus mites 'off taro' after hot water treatment at $47.5-52.5^{\circ} \mathrm{C}$ for $0-5 \mathrm{~min}(\mathrm{n}=27-245$ for each data point, three replicates for each temperature/ duration). Error bars represent the root-meansquare of the errors of the fit for each line and represent approximately uniform variability over the entire mortality range on the arcsine scale.

duration (15 s) at $52.5^{\circ} \mathrm{C}$ (Figure 1). One hundred percent mortality of Meloidogyne sp. nematodes was achieved between in 1-2 $\mathrm{min}$ at $47.5^{\circ} \mathrm{C}$, and between $30 \mathrm{~s}$ and $1 \mathrm{~min}$ at $50^{\circ} \mathrm{C}$. All nematodes were dead at $45 \mathrm{~s}$ at $52.5^{\circ} \mathrm{C}$ (Figure 2).

\section{Mite and nematode hot water tolerance observations 'on taro'}

Experiments at $52.5^{\circ} \mathrm{C}$ for $3.5 \mathrm{~min}$ and $5 \mathrm{~min}$ indicated that a longer duration would be required to achieve $99-100 \%$ mortality of $R$. minutus mites 'on taro' (Table 2). The mortality of mites in the control treatments was high, suggesting that mite handling procedures on taro would need to be improved in the future. Very few nematodes

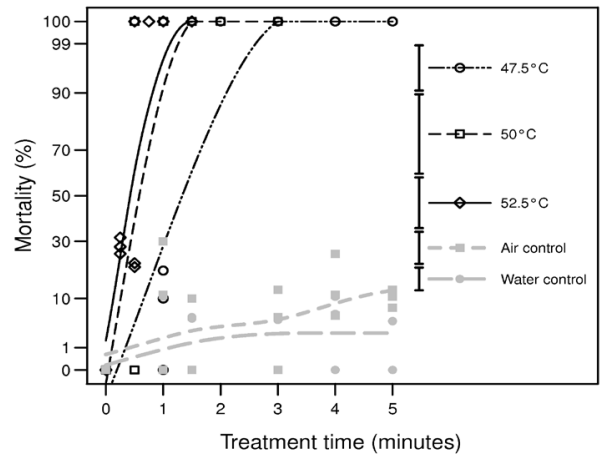

Figure 2 Percentage mortality of Meloidogyne sp. nematodes 'off taro' after hot water treatment at $47.5-52.5^{\circ} \mathrm{C}$ for $0-5 \min (n=5-21$ for each data point, three replicates for each temperature/ duration). Error bars represent the root-meansquare of the errors of the fit for each line and represent approximately uniform variability over the entire mortality range on the arcsine scale.

were found in the taro (1 dead Helicotylenchus and 1 dead Meloidogyne in each of the two temperature durations) and no live Meloidogyne sp. or Helicotylenchus sp. nematodes were present in either the untreated or hot water-treated taro. Live nematodes were found in some taro, but these were identified as bacterial or fungal feeders.

\section{DISCUSSION}

In the absence of plant material, the mortality of $R$. minutus mites and Meloidogyne sp. nematodes to HWTs tested in Samoa were similar to the mortality of Tyrophagus putrescentiae mites and Meliodogyne nr incognita nematodes exposed to HWTs in New

Table 2 Percentage mortality of Rhizoglyphus minutus mites 'on taro' after hot water treatment at $52.5^{\circ} \mathrm{C}$ for 3.5 and $5 \mathrm{~min}$.

\begin{tabular}{lccc}
\hline Treatment temperature & Treatment duration & Percent mortality $( \pm$ SE $)$ & $\mathrm{n}$ \\
\hline Air Control & $5.0 \mathrm{~min}$ & $60.56( \pm 5.27)$ & 275 \\
Water control & $3.5 \mathrm{~min}$ & $44.97( \pm 12.35)$ & 130 \\
Water control & $5.0 \mathrm{~min}$ & $30.25( \pm 12.06)$ & 207 \\
$52.5^{\circ} \mathrm{C}$ & $3.5 \mathrm{~min}$ & $69.41( \pm 11.57)$ & 85 \\
$52.5^{\circ} \mathrm{C}$ & $5 \mathrm{~min}$ & $82.37( \pm 4.80)$ & 201 \\
\hline
\end{tabular}


Zealand (Page-Weir et al. 2013). Results from both these studies showed $99-100 \%$ mortality of mites and nematodes exposed 'off taro' to $47.5-48^{\circ} \mathrm{C}$ for 3-4 $\mathrm{min}$ and to $49-50^{\circ} \mathrm{C}$ for $30 \mathrm{~s}$ and $2 \mathrm{~min}$ (Page-Weir et al. 2013). In our 'off taro' experiments, all $R$. minutus mites were dead after the shortest treatment duration $(15 \mathrm{~s})$ at $52.5^{\circ} \mathrm{C}$ and all nematodes were dead after $45 \mathrm{~s}$ at $52.5^{\circ} \mathrm{C}$.

Hot water trials testing the tolerance of $R$. minutus mites and nematodes 'on taro' indicated that treatments longer than $5 \mathrm{~min}$ at $52.5^{\circ} \mathrm{C}$ were required to achieve $99-100 \%$ mortality of mites. Lower temperature hot water treatments have been tested on root knot nematode when Wang \& McSorley (2008) incubated Meloidogyne incognita eggs and $\mathrm{J} 2$ in a test tube experiment with sand:peat mix and immersed in a hot water bath heated at $38-45^{\circ} \mathrm{C}$ for a series of time intervals. Complete mortality of $\mathrm{J} 2$ of $\mathrm{M}$. incognita was achieved at 44 and $45^{\circ} \mathrm{C}$ when treated for one hour. Tsang et al. $(2003 ; 2004)$ showed that hot water drenches disinfect roots and media of potted bamboo or palms by eliminating all the burrowing nematode, Radopholus similis. They found that a continuous hot water $\left(50^{\circ} \mathrm{C}\right)$ drenching of either bare roots or media in pots for $15 \mathrm{~min}$ (bamboo palm) or $13 \mathrm{~min}$ (fishtail palms) successfully eliminated all burrowing nematodes. HWT of seed ginger is recommended in Hawaii and the West Indies at $50^{\circ} \mathrm{C}$ for 10 min to kill nematodes and to surface-sterilize the rhizomes (Nishina et al. 1992; RADA 2012).

Further modifications to our experimental methods are required in the future to allow Meloidogyne sp. nematodes to be inoculated onto taro and recovered after HWT. Modified methods will be required to demonstrate the treatment efficacy against nematodes on taro corms. Another factor that will need to be considered is the depth that nematodes are found in the taro corm flesh. It is hypothesised that because these are tropical nematodes, they will be found at or close to the surface (F. Shah, Plant \& Food Research, personal communication). This hypothesis will be tested by examining various taro cultivars in Samoa. This information will be used to determine the treatment temperature and duration at the nematode location.

In Samoa high pressure washing is being considered for use before HWT to further reduce the risk of nematodes, mites and other surface-dwelling pests of quarantine concern on taro. High pressure washing has been successfully used to reduce fumigation rates of citrus from $\mathrm{New}$ Caledonia to New Zealand (Griffin et al. 2014). A high pressure taro washer has been designed and built at Plant \& Food Research in New Zealand and is being shipped to Samoa for testing in 2016. It may be useful to examine the combined effect of both HPW and HWT on pest mortality.

\section{ACKNOWLEDGEMENTS}

The authors acknowledge funding from the Ministry of Business, Innovation and Employment via Better Border Biosecurity (B3; www.b3nz.org). We thank Zhi-Qiang Zhang at Landcare Research for the mite identification. We appreciate the assistance of MAF Samoa staff at the research station and the Atele Packhouse. Thanks also to PFR staff who assisted with organising and supplying equipment to use in Samoa and to Nigel Bell, Lee Aalders and Farhat Shah for valuable nematode discussions.

\section{REFERENCES}

Anon 2016. Taro mite: Pacific Island countries. http://www.pestnet.org/Summaries ofMessages/Crops/Rootstubers/Taro/Mites/ Mitesexports, PacificIscountries.aspx. [accessed 14 April 2016].

Brash D, van Epenhuijsen CW 2006. Hot water treatment of taro for control of mites and namatodes. A Crop \& Food Research report prepared for Biosecurity New Zealand. Report No. 1696. 12 pp.

Buli A, Lomavatu M, Ciri M 2015. Developing cleaner export pathways for taro in Fiji and Samoa. Proceedings of the. International Symposium on Innovative Plant Protection in Horticulture, Biosecurity, Quarantine Pests, and Market Access. Eds.: C. Hale, D. Hunter, W. Roberts, R. Ikin and S. McMaugh. Acta Horticulturae 1105: 301-306. 
Cleveland WS, Grosse E, Shyu WM 1992. Local regression models. In: Chambers JM, Hastie TJ eds. Statistical Models in S, Wadsworth \& Brooks/Cole, California. Pp. 309-376.

De Lima CPF 2009. Final Report: Cost effective disinfestation treatments for Pacific horticulture. http://aciar.gov.au/files/ node/11329/PC-2008-029.pdf, Australian Centre for International Agricultural Research. 30 pp.

Griffin M, Olsson SR, Jamieson LE, Kagy V, Mille C, Connolly PG, Woolf AB 2014. Reducing the risk of importing pest-infested citrus by applying high pressure washing treatments offshore. New Zealand Plant Protection 67: 109-115.

MPI 2012. Approved Biosecurity Treatments. Ministry For Primary Industries, Wellington. http://www.biosecurity.govt.nz/files/regs/ stds/bnz-std-abtrt.pdf [accessed 14 April 2016]

Nishina MS, Sato DM, Nishijima WT, Mau RFL 1992. Ginger rood production in Hawaii. http://www.ctahr.hawaii.edu/oc/freepubs/ pdf/CFS-GIN-3A.pdf [accessed 14 April 2016].

Page-Weir NEM, Jamieson LE, Bell NL, Rohan TC, Chhagan A, Clare G, Kean AM, Davis VA, Griffin M, Connolly PG 2013. Interceptions and hot water treatment of mites and nematodes on root crops from the Pacific Islands. New Zealand Plant Protection 66: 17-28.
R Core Team 2015. R: A language and environment for statistical computing. Vienna, Austria., R Foundation for Statistical Computing, .

Rural Agricultural Development Authority 2012. Hot water treatment of ginger plant material for control of plant parasitic nematodes. Rural Agricultural Development Authority. http://www.rada.gov.jm/wp-content/ uploads/2013/11/Hot_Water_Treatment-_ GINGER.pdf [accessed 14 April 2016].

Tsang MMC, Hara AH, Sipes B 2003. Hot-water treatments of potted palms to control the burrowing nematode, Radopholus similis. Crop Protection 22(4): 589-593.

Tsang MMC, Hara AH, Sipes BS 2004. Efficacy of hot water drenches of Anthurium andraeanum plants against the burrowing nematode Radopholus similis and plant thermotolerance. Annals of Applied Biology 145(3): 309-316.

UNEP 2012. Handbook for the Montreal Protocol on Substances that Deplete the Ozone Layer. Ninth Edition. Control measures. Article 2H paragraph 6: http://ozone.unep.org/en/ handbook-montreal-protocol-substancesdeplete-ozone-layer/16

Wang KH, McSorley R 2008. Exposure time to lethal temperatures for Meloidogyne incognita suppression and its implication for soil solarization. Journal of Nematology 40(1): 7-12. 